\title{
Kajian Dinamika Kelompok Tani Usaha Ternak Sapi Potong di Kelompok Tani Nekmese Desa Manusasi Kecamatan Miomaffo Barat
}

\author{
Marsianus Falo \\ ${ }^{a}$ Fakultas Pertanian, Universitas Timor, Kefamenanu, TTU - NTT, 85613, Indonesia.
}

\section{Article Info}

\section{Article history:}

Received 1 Mei 2015

Received in revised form 24 Mei 2015

Accepted 6 Juli 2015

\section{Keywords:}

Dinamika

Kelompok Tani

Manusas

\begin{abstract}
Abstrak
Penelitian dilakukan di kelompok tani Nekmese Desa Manusasi Kecamatan Miomaffo Barat, pada bulan Maret - Mei 2014 dengan tujuan mendapatkan gambaran dinamika kelompok, mengukur kedinamisan serta mengetahui hubungan antara kedinamisan kelompok tani dengan tingkat kemampuan dalam melakukan kegiatan usahatani ternak sapi potong.. Metode yang digunakan adalah metode survey. Hasil penelitian menunjukan bahwa 1) dalam satu tahun satu ekor sapi betina dewasa memproduksi satu ekor anak sapi bakalan, kepemilikan sapi setiap anggota kelompok 4-11 ekor, jumlah keseluruhan ternak sapi di Desa Manusasi 256 ekor, sedangkan jumlah ternak sapi Kecamatan Miomaffo Barat 4601 ekor; 2) Kedinamisan terhadap usaha ternak sapi didasari oleh tujuan, struktur, fungsi, pembinaan, kekompakan, suasana, keefektifan, tekanan dan maksud tersembunyi, rata-rata petani peternak puas dengan skor rata-rata 3,916 $(78,33 \%)$ dengan penyebarannya sebanyak 22 orang $(92 \%)$, sedangkan petani peternak berpendapat cukup puas sebanyak $0,08(8,33 \%)$ 3) Hubungan kedinamisan kelompok terhadap kemampuan melakukan usaha ternak sapi petani peternak kelompok Nekmese berpendapat puas dengan skor rata-rata 4,08 (81,66\%), sedangkan berdasarkan hasil analisis Rank Sperman hubungan dinamika meliputi umur memiliki hubungan nyata terhadap kedinamisan kelompok dimana nilai $\mathrm{Rs}_{\text {hitung }}$ lebih besar $\mathrm{Rs}_{\text {tabel }}$ : umur $(0,665>0,409)$, pendidikan formal $(0,713>0,409)$, non formal $(0,624>0,409)$, pengalaman usaha $(0,641>0,409)$. Sedangkan hubungan kemampuan meliputi umur memiliki hubungan nyata dimana nilai Rs $s_{\text {hitung }}$ lebih besar Rs tabel : umur $(0,711>0,409)$, pendidikan formal $(0,696>0,409)$, non formal $(0,775>0,409)$, pengalaman $(0,695>0,409)$. (C2016 dipubikasikan oleh Agrimor.
\end{abstract}

\section{Pendahuluan}

Pembangunan pertanian secara umum mengharuskan adanya peningkatan kualitas sumber daya manusia agar dapat memanfaatkan segenap sumberdaya alam untuk kepentingan kesejahteraan manusia itu sendiri, untuk itu penyampaian teknologi kepada masyarakat terutama petani di pedesaan menjadi penting karena para petani dan peternak hanya memperoleh pengetahuan, ketrampilan dan sikap tentang suatu teknologi dari pengalaman mereka. Alternatif yang dapat digunakan dalam rangka tranfer teknologi kepada masyarakat petani yang efektif antara lain melalui pemanfaatan kelompok tani. Menurut Santosa (1999), kelompok adalah suatu unit yang terdapat beberapa individu, yang mempunyai kemampuan untuk berbuat dengan kesatuannya dengan cara dan atas dasar kesatuan persepsi. Kelompok mempunyai keragaman dalam banyak hal, yakni ukuran, lamanya, nilai-nilai dari tujuan, ruang lingkup dan yang terpenting adalah keragaman dalam ukuran kelompok. Sears et al. (1999) menyatakan bahwa kelompok kecil memiliki anggota antara tiga sampai 20 orang, apabila lebih maka disebut sebagai organisasi formal.

Menurut Cartwright dan Zander (1986), sekurang kurangnya ada tiga kondisi yang memungkinkan pembentukan suatu kelompok, yaitu 1) Kelompok yang dibentuk oleh satu orang atau lebih dengan maksud-maksud tertentu; 2) Suatu kelompok yang dibentuk Secara spontan; 3) Sekumpulan individu menjadi suatu kelompok karena diperlakukan yang sama oleh orang lain. Selanjutnya Mardikanto (1993) menambahkan bahwa ciri-ciri utama kelompok yaitu memiliki ikatan yang nyata, interaksi dan interrelasi sesama anggotanya, struktur dan pembagian tugas yang jelas, kaidah - kaidah atau norma-norma tertentu yang disepakati bersama dan keinginan dan tujuan bersama. Keberhasilan suatu kelompok pada hakikatnya, terletak pada dinamika kelompok. Dinamika kelompok merupakan kekuatan-kekuatan yang muncul dari dalam kelompok yang dicirikan oleh sembilan unsur yakni 1) tujuan kelompok; 2) struktur kelompok; 3) fungsi tugas kelompok; 4) pengembangan kelompok; 5) kekompakan kelompok; 6) suasana kelompok; 7) tekanan kelompok; 8) keefektifan kelompok, dan; 9) maksud tersembunyi.

Kabupaten Timor Tengah Utara (TTU) merupakan kabupaten yang ada di Provinsi Nusa Tenggara Timur (NTT) yang selalu mendorong masyarakat untuk pembentukan kelompok peternak. Data pada tahun 2010 (BPS Kab. TTU, 2011) menunjukkan bahwa terdapat 977 kelompok tani yang tersebar di 24 kecamatan dengan jumlah anggota berbeda-beda. Kecamatan Insana Barat memiliki kelompok tani sebanyak 54 kelompok yang tersebar di enam desa dan satu kelurahan dengan tahun pembentukan berkisar tahun 1994-2000 dan setiap kelompok tani memiliki jumlah anggota sebanyak 20-119 anggota.

Di Kecamatan Miomaffo Barat masyarakatnya dapat berusahatani tanaman pangan juga berusahatani ternak sapi potong. Hasil sensus populasi ternak sapi potong menurut kecamatan dan kecamatan Miomaffo Barat tahun 2012 mencapai 4.601ekor, sedangkan secara keseluruhan tingkat populasi ternak sapi potong di Kab. TTU mencapai 98.631 ekor, (BPS Kab. TTU, 2013). Sedangkan data BPS Prop. NTT (2013) di Provinsi NTT populasi tahun 2012 tercatat mencapai 778.633 ekor. Kondisi usaha ternak sapi ini mengindikasikan bahwa usahatani ternak sapi umumnya dan khususnya ternak sapi potong baik mutu maupun jumlahnya terus dapat dilakukan, namun karena pola peternakan yang masih bersifat tradisional, pakan ternak tidak tersedia sepanjang tahun, bertambah luas daerah pertanian dan pemukiman penduduk serta kemampuan yang tidak mendukung, dapat menjadi penyebab utama dalam pencapaian tujuan kelompok-kelompok tani yang ada. Berdasarkan latar belakang tersebut, maka dianggap penting untuk dilakukan penelitian tentang kajian dinamika kelompok tani usaha ternak sapi potong di kelompok tani Nekmese Desa Manusasi Kecamatan Miomaffo Barat Kabupaten TTU yang bertujuan untuk 1) Mendapatkan gambaran dinamika kelompok tani usaha ternak sapi potong; 2) mengukur kedinamisan kelompok tani; 3) mengetahui hubungan antara kedinamisan kelompok tani dengan tingkat kemampuan dalam melakukan kegiatan usahatani ternak sapi potong.

\section{Metode}

Penelitian dilaksanakan di Desa Manusasi Kecamatan Miomaffo Barat Kabupaten TTU pada bulan Maret sampai Mei 2014. Metode pengambilan sampel dilakukan melalui beberapa tahap yaitu: 1) Tahap pertama pengambilan sampel digunakan metode kuota sampling yakni dari total jumlah kelompok tani di Desa Manusasi sebanyak 6 kelompok tani hanya diambil satu kelompok tani yakni kelompok Tani Nek'mese dengan dasar pertimbangan bahwa Kelompok Tani ini yang pertama di Kecamatan Miomaffo Barat mendapat perhatian dari pemerintah berupa bantuan usaha pengembangan usaha ternak sapi potong; 2) Tahap kedua penentuan responden secara sensus yaitu dari keseluruhan jumlah anggota kelompok tani Nekmese sebanyak 119 orang dan dari total/jumlah anggota tersebut diambil $20 \%$ sehingga responden berjumlah 24 orang.

Pengumpulan data dilakukan dengan menggunakan metode survey, data yang dikumpulkan berupa data primer dan data sekunder. Data primer adalah data yang diperoleh dari wawancara langsung dengan responden, diperoleh melalui daftar pertanyaan yang telah disiapkan, sedangkan data sekunder diperoleh dari instansi / lembaga terkait. Data yang dikumpulkan dan dianalisis sesuai dengan tujuan yang ingin dicapai yaitu 1) Untuk menjawab tujuan pertama yaitu gambaran kelompok tani usaha ternak sapi potong menggunakan pertanyaan yang telah disiapkan dalam bentuk quasioner dan selanjutnya dianalisis dengan analisis deskriptif; 2) Untuk menjawab tujuan kedua yaitu kedinamisan kelompok tani dan untuk mengukurnya dari responden dengan kategori kedinamisan sangat tidak puas, tidak puas, cukup puas dan sangat puas; 3) Untuk menjawab tujuan ketiga yaitu hubungan antara kedinamisan kelompok tani dengan tingkat kemampuan dalam melakukan kegiatan usahatani ternak sapi potong dilakukan analisis korelasi Rank Spearman sesuai petunjuk Djarwanto, (2003).

\section{Hasil dan Pembahasan}

3.1 Gambaran Umum Usahatani Ternak Sapi Potong

Pada umumnya petani di Kecamatan Miomaffo Barat dapat mengusahakan berbagai macam jenis komoditi pertanian terutama pangan, palawija dan hortikultura serta dapat mengusahakan ternak sapi potong untuk memenuhi kebutuhan keluarga atau rumah tangga. Usaha ternak sapi potong dapat dijalankan dalam bentuk kelompok dan seluruh anggota dapat terlibat langsung karena menjadi keputusan bersama. Dari jenis-jenis kegiatan yang dilakukan kelompok tani Nekmese tersebut didasari oleh unsur-unsur dinamika yang meliputi tujuan, struktur, fungsitugas, pembinaan dan pengembangan, kekompakan, suasana, keefektifan, tekanan/ketegangan dan maksud tersembunyi.

Unsur-unsur dinamika tersebut didasari oleh anggota sebagai kekuatankekuatan yang dimiliki dalam kelompok seperti percaya diri sebagai anggota bahwa benar-benar menjadi anggota kelompok tidak dipaksa dan jenis kegiatannya jelas, percaya pemimpin bahwa pemimpin yang dipilih dipercaya penuh untuk menggerakkan kelompok, percaya aturan bahwa aturan yang dibuat berdasarkan kesepakatan bersama untuk ditaati anggota kelompok. Dari kekuatan-kekuatan ini oleh anggota menjadi dasar untuk dapat mengembangkan jenis usaha ternak sapi potong sebagai upaya peningkatan produksi dan produktivitas yang dihasilkan.

Menurut kelompok Tani Nekmese, dinamika yang dibangun melaui kerja sama anggota saling percaya saling berhubungan maupun saling berkoordinas atau berkomonikasi antara anggota yang satu dengan anggota yang lain maupun antara anggota dengan pengurus kelompok. Kerja sama kelompok menjadi utama dan dapat disepakati bersama anggota dalam setiap kegiatan kelompok. Kegiatan 
kelompok yang dijalankan adalah dengan tujuan untuk menyelesaikan dan memajukan usaha-usaha kelompok demi peningkatan produksi dan pendapatan. Setiap tugas yang dijalankan oleh anggota dan pengurus kelompok selalu dapat terbuka dan saling percaya serta menjaga kebersamaan anggota dan pengurus agar tetap terjalin hubungan kerjasamanya. Setiap hubungan kerjasama dengan pihak lain selalu dapat disampaikan dalam rapat kelompok dan seluruh anggota dapat mengetahuinya. Hal ini dapat tertanam karena sudah menjadi kesepakatan yang dibuat dalam aturan kelompok. Maka dengan ini kelompok tani Nekmese dalam membangun hubungan kerjasama anggota dan pengurus serta dengan pihak lain sudah menjadi terbiasa. Salah satu hal yang menarik dapat dilakukan oleh kelompok Tani Nekmese adalah pada pertemuan kelompok ataupun kunjungan dari instansi terkait pemberitahuannya cukup dengan alat pengeras suara anggota sudah tahu adanya pertemuan kelompok. Kerjasama ini terbangun dengan penyadaran atau pemberian motivasi dari awal terutama pembentukan pribadi dan karakteristik anggota sehingga hubungan kerjasamanya menjadi kuat dan masing-masing anggota memiliki tujuan yang hendak dicapai bersama yaitu kesejahteraan anggota. Hal ini dapat terlihat melalui unsur-unsur dinamika yang ada di dalam kelompok tani Nekmese.

Tujuan kelompok adalah untuk meningkatkan dan mengembangkan kemampuan usaha dalam meningkatkan produksi dan produktivitas, menciptakan kondisi yang berkesinambungan dan berperan serta aktif dengan pihak-pihak terkait dalam membangun sub sektor peternakan khususnya dan pembangunan pada umumnya. Sejak awal membentuk kelompok tani Nekmese adalah setiap anggota terbangun dengan motivasi yang tinggi untuk menjadi diri sendiri bersama kelompok terutama dilandasi oleh rasa percaya diri sebagai anggota, percaya pemimpin sebagai penggerak jalannya kelompok, percaya aturan sebagai orang yang ikut merencanakan dan menyusun serta memutuskan aturan dan saling bekerjasama untuk mencapai kesejahteraan baik secara kelompok maupun individu. Hal-hal yang dicapai anggota kelompok Nekmese dengan adanya usaha ternak sapi potong antara lain membangun rumah menyekolahkan anak dan memenuhi kebutuhan lain dalam keluarga. Hal ini menjadi lebih banyak untuk berbuat dan menyadari akan pentingnya sebuah kebersamaan dalam berkelompok.

Struktur kelompok adalah status pembagian tugas urutan kekuasaan dalam kelompok dimana struktur berhubungan dengan pengambilan keputusan dan bagian alir komunikasi. Dalam penelitian ini informasi yang diperoleh bahwa pembentukan stuktur organisasi kelompok tani Nekmese dapat dipilih dalam rapat kelompok yang terdiri dari ketua, sekrertaris dan bendahara. Sedangkan ketua - ketua bidang dan ketua seksi lainnya dapat dipilih oleh badan pengurus yang terbentuk dan informasi yang diperoleh dalam wawancara ini adalah pengurus kelompok dalam hal ini ketua kelompok, sejak terpilih sampai sekarang belum terganti oleh karena memiliki hubungan yang luas dan selalu memberi ruang kepada anggota dalam rapat untuk saling mengoreksi apabila ada kesalahan yang dilakukan, baik oleh anggota maupun pengurus. Struktur organisasi kelompok tani Nekmese dapat dilihat pada Gambar 1.

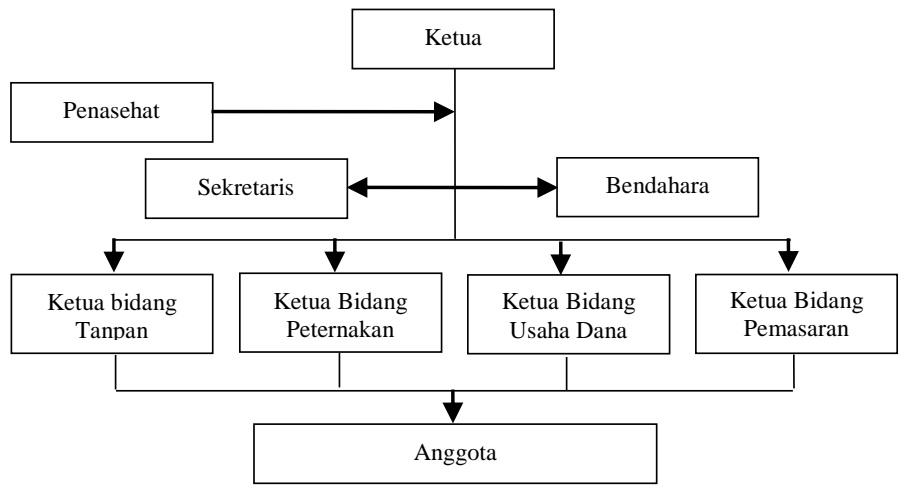

Gambar 1. Struktur Organisasi Kelompok Tani Nekmese

Fungsi kelompok tani adalah sebagai kelas belajar, unit produksi dan wahana kerjasama. Fungsi yang dijalankan kelompok tani Nekmese menurut anggota bahwa kegiatan yang dijalankan oleh pengurus terhadap pembinaan mental anggota dan kerjasamanya dalam menyikapi inovasi dan teknologi baru terutama untuk meningkatkan hasil dan jumlah produksi usaha ternak sapi potong dapat diaplikasikan dengan pengalaman dengan maksud untuk mencapai tujuan yaitu pencapaian kesejahteraan anggota kelompok. Koordinasi atau komonikasi yang dibangun pengurus dan anggota selalu mengedepankan partisipasi kegiatan anggota, kerjasama anggota, hubungan persahabatan anggota, saling percaya dan terbuka serta menghormati dan menghargai kegiatan yang dihasilkan. Tugas yang dijalankan anggota kelompok ditemukan berbagai kegiatan meliputi kegiatan usaha ternak sapi potong antara lain : pembibitan sapi potong,pemeliharaan sapi potong, pnyediaan pakan, air, kandang, penanganan kesehatan ternak, produksi/produktivitas, pemasaran, pembuatan pupuk bokashi dan kompos, sampai pada pemanfaatan kotoran sapi yang mentah menjadi tenaga listrik yang disebut biogas.

Pembinaan dan pengembangan kelompok adalah suatu proses atau perbuatan mengembangkan pengetahuan dan ketrampilan, sikap para anggota dan arahan-arahan serta kebijaksanaan pembangunan lebih mudah disampaikan dan disebarluaskan melalui anggota kelompok. Pembinaan atau motivasi anggota kelompok lebih diarahkan kepada peningkatan produksi usahatani, sedangkan pengembangan kelompok menyangkut peningkatan kemampuan anggota kelompok tani terutama dalam pelaksanaan fungsi dan tugasnya. Hal yang dapat ditemukan di kelompok tani Nekmese adalah tugasnya sebagai anggota melaksanakan kegiatan-kegiatan kelompok yang telah disusun dan disepakati bersama, dan pelaksanaannya digerakkan dan diawasi oleh pengurus yang hasilnya dari anggota, oleh anggota dan untuk anggota.

Kekompakan kelompok adalah keadaan atau kondisi dimana aktivitas anggota membangun semangat yang tinggi dan kesetiaan yang mendalam pada kelompok sehingga secara bersama-sama saling memberi nuansa hidup, menjadi diri sendiri dan kreatif. Kekompakan kelompok merupakan suatu kondisi dimana aktivitas anggota membangun semangat yang tinggi dan rasa kesetiaan yang mendalam pada kelompok secara bersama-sama, sehingga ikatan emosional antara anggota saling mengenal diri sendiri dan akan menimbulkan kekompakan yang kuat antara kelompok (Charlres, 1991). Kekompakan yang terjadi di kelompok Nekmese menjadi hal yang sangat berarti terutama sebagai dasar dari kepribadian anggota adalah percaya diri sebagai anggota, percaya pemimpin sebagai orang yang menggerakkan kelompok, percaya kepada peraturan dimana sebagai orang yang turut memberikan dan mendukung keputusan kelompok dalam rapat anggota. Hal ini dapat diwujudkan melalui kegiatan-kegiatan kelompok seperti rapat kelompok atau kunjungan dari instansi terkait pemberitahuannya disampaikan dengan menggunakan alat pengeras suara anggota dapat mengetahuinya sebagai tanda untuk berkumpul atau rapat kelompok.

Suasana kelompok adalah persatuan dalam kelompok yang merupakan satu ikatan kekuatan dan sifat eklusif, kbersamaan yang dinamis oleh anggota kelompok dan para pengurus kelompok.Dalam Kelompok Nekmese perkumpulan menjadi lebih penting karena setiap anggota memiliki derajad yang sama, kewajiban yang sama dan hak yang sama terutama dalam setiap kegiatan kelompok. Suasana yang ditampilkan dapat memberikan kesan kepada semua anggota terutama persatuan yang menjadi satu ikatan kekuatan dan kebersamaan. Anggota kelompok tani tidak akan efektif menjalankan tugas dan kewajibannya, pengendalian, pengarahan, dan kerjasama dengan pemimpin, artinya hubungan yang ada sperti ini merupakan peluang bagi anggota untuk mengkomonikasikan hasil berpikir antara pemimpin dan anggota. Suasana yang ditampilkan di kelompok Nekmese mengutamakan suasana yang aman dan penuh persahabatan. Perbedaan merupakan sebuah dinamika yang berjalan dalam kelompok Nekmese.

Keefektifan kelompok adalah suatu proses pemberian motivasi kerja yang dilakukan terus-menerus untuk mencapai tujuan kelompok yang efisien dan dapat mencapai tujuan khusus yang ditetapkan bersama. Anggota kelompok tani tidak akan efektif menjalankan tugas dan kewajibannya, pengendalian, pengarahan dan kerjasama dengan pemimpin, artinya hubungan yang ada seperti ini merupakan peluang bagi anggota untuk mengkomonikasikan hasil berpikir antara pemimpin dan anggota.Keefektifan dalam hal ini pemberian motivasi kerja yang diarahkan kepada perencanaan dan penyusunan kegiatan kelompok serta pelaksanaannya yang efektif dan dapat terselesaikan sesuai harapan anggota.

Tekanan atau ketegangan kelompok adalah suatu kesalah pahaman di antara anggota atau perbedaan pendapat dan berakibat terjadi pemisahan di antara sesama anggota dan menjadi penghambat dalam proses kegiatan untruk mencapai tujuan bersama. Ketegangan atau tekanan dalam sebuah kelompok/organisasi terjadi karena dipengaruhi oleh faktor interen maupun eksteren. Faktor-faktor interen antara lain konflik/perbedaan pendapat, otoriter dan persaingan. Sedangkan faktor eksternal meliputi tantangan, serangan dan sanksi. Hal-hal ini yang sering terjadi dalam sebuah kelompok. Namun keadaan ini oleh kelompok Nekmese sudah termotifasi dari awal karna kelompok yang terbentuk secara spontan atau atas inisiatif anggota sendiri dengan mengedepankan aspek-aspek dinamika kelompok dalam mencapai tujuan. Tujuan yang ingin dicapai adalah kesejahteraan anggota karena itu kesepakatan anggota untuk menjaga persahabatan dan kekeluargaan dapat terjamin dan secara bersama-sama berpendapat bahwa lebih baik menciptakan dan melaksanakan kegiatan daripada menciptakan konflik diantara anggota kelompok dan pengurus yang tidak memiliki keuntungan diri.

Maksud tersembunyi adalah suatu proses pergerakkan yang dilakukan atau dijalankan oleh pengurus maupun anggota dengan pihak lain dan berusaha mendatangkan program atau berusaha menciptakan usaha-usaha baru untuk kelompok. Penumbuhan motivasi yang didasari kekeluargaan menjadi tujuan bersama kelompok dalam mencapai tujuan. Program/kegiatan tanpa disadari anggota dapat diketahuinya melalui rapat anggota yang disampaikan oleh badan pengurus dan anggota membuat keputusan untuk menerimanya atau tidak. Artinya program atau kegiatan yang diterima atau tidaknya bergantung pada keputusan rapat anggota, karena yang melaksanakan program atau kegiatan adalah anggota. Sejauh ini pelaksanaan kegiatan dikelompok tani Nekmese menganut asas kekeluargaan yaitu dari anggota, oleh anggota dan untuk anggota. Segala bentuk kegiatan yang dijalankan dapat diketahui dan diputuskan oleh anggota karena keputusan tertiggi berada pada rapat anggota. Pergerakkan yang dilakukan kelompok Nekmese seperti hubungan kerjasama dengan pengusaha dalam penjualan ternak sapi potong dengan kesepakatan pengusaha langsung ambil di tempat kelompok dengan harga yang disepakati bersama. 


\subsection{Dinamika Kelompok Tani}

Berdasarkan hasil penelitian, usaha ternak sapi potong menurut anggota kelompok merupakan suatu usaha yang sangat bermanfaat bagi anggota yaitu dapat meningkatkan nilai ekonomi dan peningkatan pola hidup petani. Sesuai hasil perhitungan rata-rata skor dinamika terhadap usaha ternak sapi potong di kelompok Nekmese sebesar 3,91 atau sebesar 78,33\% dengan penyebaran 92\% atau 22 orang petani peternak termasuk dalam kategori anggota puas terhadap dinamika usaha ternak sapi potong yang dijalankan. Tingkat kepuasan anggota terhadap dinamika usaha dapat dilihat pada Tabel 1 .

\begin{tabular}{clcc}
\multicolumn{5}{c}{ Tabel } & 1. Tingkat Kepuasan Anggota Terhadap Dinamika Usaha \\
\hline No & \multicolumn{1}{c}{ Kategori } & Jumlah (orang) & Persentasi (\%) \\
\hline 1 & Sangat Tidak Puas & - & - \\
2 & Tidak Puas & - & - \\
3 & Cukup puas & 2 & 8 \\
4 & Puas & 22 & 92 \\
5 & Sangat puas & - & - \\
\hline Total & & 24 & 100 \\
\hline
\end{tabular}

Sumber : Data Primer Diolah 2014

Hasil analisiss Rank Spermaen menunjukkan umur terhadap dinamika usaha ternak sapi potong memiliki nilai $\mathrm{Rs}_{\text {hitung }}$ lebih besar $\mathrm{Rs}_{\text {tabel }}(0,665>0,409)$, pendidikan formal dengan dinamika memiliki nilai $\mathrm{Rs}_{\text {hitung }}$ lebih besar $\mathrm{Rs}_{\text {tabel }}$ $(0,713>0,409)$, pendidikan non formal dengan dinamika memiliki nilai $\mathrm{Rs}_{\text {hitung }}$ lebih besar $\mathrm{Rs}_{\text {tabel }}(0,624>0,409)$ dan pengalaman usaha terhadap dinamika memiliki nilai Rs shitung lebih besar $\mathrm{Rs}_{\text {tabel }}(0,641>0,409)$. Hasi analisis Rank Spermaen dapat dilihat pada Tabel 2.

Tabel 2. Hasi analisis Rank Spermaen

\begin{tabular}{clccc}
\hline No & \multicolumn{1}{c}{ Hubungan } & $\mathrm{Rs}_{\text {hitung }}$ & $\begin{array}{c}\mathrm{Rs}_{\text {tabel }} \\
\propto 0,05\end{array}$ & Kategori \\
\hline 1 & Umur dan Dinamika & 0,665 & 0,409 & Nyata \\
2 & $\begin{array}{l}\text { Pendidikan formal dan } \\
\text { Dinamika }\end{array}$ & 0,713 & 0,409 & Nyata \\
& $\begin{array}{l}\text { Pendidikan non formal dan } \\
3\end{array}$ & 0,624 & 0,409 & Nyata \\
4 & Dinamika & 0,641 & 0,409 & Nyata \\
\hline Sumber : Data Primer Diolah 2014
\end{tabular}

\subsection{Kemampuan Usahatani Ternak Sapi Potong}

Kemampuan usaha adalah suatu cara atau bentuk usaha pemanfaatan potensi sumberdaya yang dimiliki dan dijalankan oleh seseorang atau beberapa orang baik berupa bahan mentah maupun bahan jadi secara berkesinambungan untuk mencapai tujuan. Kelompok tani Nekmese terbentuk karena memiliki kesamaan mata pencaharian, mampu dimanfaatkan untuk kegiatan usaha yang berkesinambungan dan dapat meningkatkan nilai tambah bagi keluarganya. kegiatan ini dapat berjalan karena sudah termotivasi sejak awal terbentuknya kelompok Nekmese, dengan kegiatan-kegiatannya meliputi kegiatan pertanian tanaman pangan dan peternakan. Kegiatan peternakan yang dijalankan kelompok ini adalah pembibitan dan pengembangan sapi potong, pemeliharaan, penyediaan pakan, kandang, air ,kesehatan, produksi dan produktivitas serta pemasaran, dan juga penerapan teknologi pembuatan pupuk bokashi, kompos, biogas. Proses pembuatan biogas ini sangat teknis dimana kotoran ternak sapi yang mentah difermentasi yang kemudian dapat menghasilkan tenaga listrik dan dipakai untuk penerangan.

Pembibitan adalah suatu cara atau teknik budidaya yang dapat dilakukan untuk mengembangkan dan meningkatkan produksi dan produktivitas usahatani ternak sapi potong. Pembibitan ternak sapi potong yang dijalankan oleh kelompok tani Nekmese sejak tahun 2000 hingga sekarang. Dalam proses hasil produksi dan produktivitasnya meningkat seiring dengan diberlakukannya pemilihan sapi betina bibit dan pejantan bibit untuk memperoleh keturunan yang baik, sehingga anggota kelompok peternak menjadi mampu dalam menghasilkan produksi dan produktivitas yang meningkat. Kemampuan kelompok tani dapat diukur melalui kelas kelompok tani yaitu kelas yang tinggi dapat disimpulkan berperan baik dalam penerapan teknologi maupun sabta usahatani, kegiatankegiatan usahatani ternak sapi potong yang dilakukan oleh anggota kelompok Nekmese dan menjadi berkembang untuk meningkatkan hasil produksi dan jumlah produksi. Kegiatan-kegiatan pembibitan sapi potong dalam peningkatan hasil dan jumlah produksi dilakukan melalui perkawinan ternak berupa kawin alam dan kawin suntik.

Dalam melakukan kawin alam terhadap ternak sapi potong petani peternak melakukan beberapa hal antara lain dengan memilih dan menyeleksi ternak betina produktif maupun pejantan. Hal-hal yang diseleksi oleh anggota peternak Nekmese untuk ternak betina meliputi fisik besar, umur 2 tahun, tinggi $2,5 \mathrm{~m}$, warna bulu merah, kaos kaki, mulut putih, ekor putih, telinga dalam putih, matanya bersih, sedangkan pejantan meliputi fisik besar, umur 2 tahun, warna bulu hitam, mulut putih, kaus kaki, telinga dalam putih, matanya bersih, tinggi badan 2,8 $\mathrm{m}$ dan tidak berasal dari turunan induk. Kegiatan kawin alam ini yang dominan dijalankan anggota karena tidak memerlukan penanganan teknis oleh petugas peternakan. Proses perkawinannya hanya dibutuhkan pengamatan khusus waktu ternak betina birahi atau minta kawin, langsung dikawinkan dengan pejantan yang sudah disiapkan. Dari hasil penyeleksian atau pemilihan ternak betina maupun pejantan adalah tujuannya untuk memperoleh turunan yang baik, tidak diisyaratkan seperti ternak sapi seperti kakaknya kambing.

Inseminasi buatan atau kawin suntik merupakan suatu cara yang dilakukan dengan membekukan sperma dari penjantan sapi bibit yang kemudian disuntikkan kepada ternak betina yang birahi atau siap kawin. Kegiatan ini dapat dilakukan untuk memperoleh turunan yang baik. Hal ini dapat diperlukan perhatiaan khusus karena kegiatan ini lebih bersifat teknis dan yang melakukan penyuntikan atau kawin suntik adalah petugas teknis peternakan sedangkan anggota peternak dituntut untuk melakukan pengamatan secara rutin terhadap ternak yang birahi untuk dilakukan penanganan.

Pemeliharaan adalah perbuatan atau cara yang dilakukan oleh petani peternak untuk mengembangkan usahataninya dengan melakukan kegiatankegiatan terhadap kebutuhan ternak. Pemeliharaan ternak sapi potong yang dilakukan oleh kelompok Nekmese adalah dengan cara siang dilepas dan dapat dikandangkan pada malam hari, pemberian makanan yang teratur dan pemberian makanan tidak pada satu jenis makanan saja. Oleh karena itu pemeliharaan dan pengelolaan tenak sapi potong sangat berperan penting dalam memenuhi kebutuhan masyarakat. Hal-hal yang menjadi pendukung keberhasilan ternak sapi potong meliputi orang atau pemilik ternak itu sendiri, lingkungan dan kebutuhan pakan yang tersedia sepanjang tahun.

Penyediaan pakan adalah hal-hal yang dilakukan oleh petani peternak kelompok Nekmese meliputi penanaman dan penyediaan pakan ternak berupa lamtoro, turi, gamal dan kingres dengan maksud untuk kebutuhan makanan ternak dan mengatasi kekurangan pakan dimusim panas. Hal ini menjadi alasan utama dalam berusahatani ternak sapi potong. oleh karena itu petani peternak harus bekerja keras untuk menyiapkan pakan sesuai hasil dan jumlahnya. Kegiatan dapat dilakukan oleh anggota kelompok Nekmese.

Air adalah sumber kehidupan ternak pada saat mengalami rasa haus dan menjadi kebutuhan setiap harinya. Penyediaan air merupakan kebutuhan yang sangat penting bagi ternak dalam membutuhkan air untuk minum dan juga untuk pembersihan kandang agar tehindar dari bau dan gangguan fisik lainnya seperti penyakit. Kegiatan ini dapat dilakukan atas kerjasamanya dengan pemerintah dan membangun embung-embung maupun sumur untuk kebutuhan ternak. Upaya ini sangat bermanfaat bagi kelangsungan hidup ternak dan petani peternak itu sendiri.

Kandang adalah tempat atau penampungan untuk ternak pada malam hari atau siang hari dan merasa aman dari setiap bentuk gangguan, baik secara fisik maupun dari mental seseorang. Kandang sangat diperlukan teutama untuk keamanan ternak itu sendiri. Kegiatan yang dilakukan petani peternak adalah membuat kandang untuk betina dengan ukuran 8 x $15 \mathrm{~m}$ ( kandang penampung ) dan kandang untuk jantan ukuran 1,5 x 2 m (kandang jepit), dengan bahanbahannya dari bambu atau kayu yang kuat, dengan syarat kandang berjarak dari rumah 5-10 m, system kandang yang dibuat terbuka, tersedia tempat penampung kotoran, pada tempat yang kering dan mendapat sinar matahari.

Kesehatan adalah suatu keadaan fisik ternak yang mengalami rasa aman dari gangguan penyakit. Kesehatan ternak dapat berpengaruh terhadap fisik dan perkembangannya terutama dalam peningkatan produksi dan produktivitas/jumlah. Hal-hal yang dilakukan dalam penanganan kesehatan ternak meliputi pemberian kekebalan tubuh (vaksinasi) dan pengobatan. Kegiatan ini sudah menjadi terbiasa dalam menjaga kondisi kesehatan hewan. Pemberian kekebalan tubuh terhadap ternak dapat dilakukan setiap enam bulan sekali, dengan tujuan agar terhindar dari penyakit maupun gangguan fisik lainnya. Jenis - jenis obat yang digunakan untuk vaksinasi adalah SE, dengan penggunaan dosis adalah untuk ternak sapi umur 3 bulan ke atas 3 cc/ekor, untuk pengobatan karena penyakit, (mengorok, muka bengkak, gementar, keluar cairan putih lewat mulut dan hidung, berak darah) obat yang digunakan teramycin, medosi, sulfastrong, vitovyt dengan dosis yang digunakan untuk sapi umur 3-18 bulan 5cc/ekor sedangkan umur 18 bulan ke atas $6-10$ cc/ekor, dan kegiatan vaksin dan pengobatan ini dapat dilakukan oleh petugas teknis dinas peternakan bersama anggota kelompok yang sudah terlatih terhadap cara vaksin dan melakukan pengobatan.

Produksi dan produktivitas adalah hasil dari perkawinan antara ternak betina dan jantan untuk menghasilkan turunan baru.Ternak sapi potong dapat berproduksi dengan baik apabila dapat memperhatikan beberapa hal seperti fisik ternak itu sendiri, kriteria ternak, kesehatan, dan pakan ternak. Hal-hal ini yang menjadi perhatian petani peternak kelompok Nekmese dalam peningkatan produksi dan produktivitas ternak sapi potong serta menjadi usaha yang mendatangkan nilai yang tinggi terutama memiliki manfaat seperti dapat dijual, dagingnya dapat dikonsumsi, dapat diolah sebagai dendeng, abon, sate, sei dan bakso dan lain-lain.

Pemasaran adalah serangkaian kegiatan penjualan produk yang dilakukan oleh petani dengan pedagang ataupun pengusaha dengan tujuan saling kerjasama dalam usaha penjualan dan pembelian. Pemasaran atau penjualan sapi potong sangat dipengaruhi oleh kondisi fisik ternak itu sendiri,terutana dalam penyediaan dan pemberian pakan ternak untuk menjaga kondisi dan fisiknya. Penjualan atau pemasaran ternak yang dilakukan kelompok Nekmese adalah penjualannya secara berkelompok dengan mendatangkan pengusaha ditempat kelompok tani. Secara umum menjadi lebih baik karena posisi tawar antara pengusaha dan kelompok menjadi kuat dan sama-sama memberikan keuntungan.

Sesuai hasil penelitian, menurut anggota kelompok Nekmese, klasifikasi/tabel harga untuk ternak pejantan/penggemukan dan ternak betina per berat badan hidup $250 \mathrm{~kg}$ dengan harga per $\mathrm{kg}$ Rp.20.200, $275 \mathrm{~kg}$ dengan harga Rp.20.400, 300 kg dengan harga Rp.20.600 dan $300 \mathrm{~kg}$ ke atas dengan harga 
Rp.20.800. Sedangkan untuk ternak betina harga disesuaikan dengan fisik atau besarnya ternak yaitu antara Rp.3000.000 sampai Rp 4000.000 per ekor. Sedangkan harga daging dipasar per kg Rp.50.000.

Rata-rata skor kemampuan terhadap usaha ternak sapi potong di Desa Manusasi Kecamatan Miomaffo Barat sebesar 4,08 atau sebesar 81,16\% dengan penyebaran $92 \%$ atau 22 orang petani perternak termasuk dalam kategori kemampuan anggota puas, secara lengkap dapat dilihat pada Tabel 3 .

Tabel 3. Skor Kemampuan Terhadap Usaha Ternak Sapi Potong

\begin{tabular}{clcc}
\hline No & \multicolumn{1}{c}{ Kategori } & Jumlah (orang) & Persentasi (\%) \\
\hline 1 & Sangat Tidak Puas & - & - \\
2 & Tidak Puas & - & - \\
3 & Cukup puas & - & - \\
4 & Puas & 22 & 92 \\
5 & Sangat puas & 2 & 8 \\
\hline Total & & 24 & 100 \\
\hline
\end{tabular}

Sumber : Data Primer Diolah 2014

Sedangkan hasil analisis Rank Sperman terhadap kemampuan yaitu antara umur dan kemampuan dalam melakukan usaha ternak sapi potong mempunyai hubungan yang nyata dimana nilai $\mathrm{Rs}_{\text {hitung }}$ lebih besar $\mathrm{Rs}_{\text {tabel }}(0,711>0,409)$, pendidikan formal terhadap kemampuan dimana $\mathrm{Rs}_{\text {hitung }}$ lebih besar $\mathrm{Rs}_{\text {tabel }}(0,696$ $>0,409)$, pendidikan formal terhadap kemampuan dimana $\mathrm{Rs}_{\text {hitung }}$ lebih besar $\mathrm{Rs}_{\text {tabel }}(0,775>0,409)$, dan pengalaman usaha terhadap kemampuan dimana nilai $\mathrm{Rs}_{\text {hitung }}$ lebih besar $\mathrm{Rs}_{\text {tabel }}(0,695>0,409)$. Hasil analisis hubungan antara faktorfaktor yang mempengaruhi kemampuan anggota terhadap usaha ternak sapi potong di kelompok Nekmese Desa Manusasi Kecamatan Miomaffo Barat dapat dilihat pada Tabel 4

Tabel 4. Hasi analisis Rank Spermaen

\begin{tabular}{clccc}
\hline No & \multicolumn{1}{c}{ Hubungan } & $\mathrm{Rs}_{\text {hitung }}$ & $\begin{array}{c}\mathrm{Rs}_{\text {tabel }} \\
\propto 0,05\end{array}$ & Kategori \\
\hline 1 & $\begin{array}{l}\text { Umurdan kemampuan } \\
2\end{array}$ & 0,711 & 0,409 & Nyata \\
& $\begin{array}{l}\text { Pendidikan formal dan } \\
\text { kemanan }\end{array}$ & 0,696 & 0,409 & Nyata \\
3 & $\begin{array}{l}\text { Pendidikan non formal dan } \\
\text { kemampuan }\end{array}$ & 0,775 & 0,409 & Nyata \\
4 & $\begin{array}{l}\text { Pengalaman dan kemampuan } \\
\text { anggota }\end{array}$ & 0,695 & 0,409 & Nyata \\
\hline
\end{tabular}

Sumber : Data Primer Diolah 2014

\section{Simpulan}

Kegiatan usahatani ternak sapi potong Kelompok Tani Nekmese meliputi kegiatan pembibitan, pemeliharaan, penyediaan hijauan makanan ternak/pakan, penyediaan kandang, penyediaan air, penanganan kesehatan, produksi dan produktivitas serta pemasaran. Dari kegiatan-kegiatan tersebut petani peternak puas dengan skor rata-rata 4,08 atau $81,66 \%$, dengan penyebarannya $92 \%$ atau 22 orang petani berpendapat puas dengan usaha ternak sapi potong. Sedangkan petani peternak sangat puas dengan skor rata-rata 0,08 atau $1,66 \%$, dengan penyebarannya $8 \%$ atau 2 orang petani berpendapat sangat puas dengan usaha ternak sapi potong.

Kedinamisan kelompok usaha ternak sapi potong yang dibangun melalui hubungan kerjasama antar anggota kelompok tani usaha ternak sapi potong yang terbentuk tercipta hubungan yang dinamis melalui kegiatan-kegiatan usaha yang dibangun anggota dan keberhasilan kegiatan kelompok didasari oleh 1) Kepercayaan diri sebagai anggota bahwa menjadi anggota kelompok untuk mengembangkan diri dan mendapat pengalaman, pengetahuan dan ketrampilan serta saling bekerjasama diantara anggota maupun dengan pengurus kelompok 2) Kepercayaan terhadap pemimpin (pengurus) dimana pemimpin/pengurus adalah penggerak jalannya kelompok. Pemimpin/pengurus dapat merencanakan dan menyusun program kegiatan yang disetujui anggota dan diputuskan oleh anggota dan dijalankan oleh anggota untuk pencapaian tujuan bersama; 3) Kepercayaan terhadap aturan. Dinamika anggota terhadap usaha ternak sapi potong di kelompok Nekmese Desa Manusasi memiliki rata-rata puas dengan skor rata-rata 3,916 atau sebesar 78,33\%, penyebarannya sebanyak $92 \%$ atau 22 orang anggota puas terhadap usaha ternak sapi potong.

Hubungan antara umur dan dinamika terhadap usaha ternak sapi potong mempunyai hubungan yang nyata dimana nilai $\mathrm{Rs}_{\text {hitung }}$ lebih besar dari $\mathrm{Rs}_{\text {tabe }}$ yaitu 0,665>0,409, pendidikan formal dan dinamika angggota kelompok terhadap usaha ternak sapi potong mempunyai hubungan yang nyata dimana nilai Rs ${ }_{\text {hitung }}$ lebih besar dari $\mathrm{Rs}_{\text {tabel }}$ yaitu 0,713>0,409, pengalaman dan dinamika usaha ternak sapi potong mempunyai hubungan yang nyata dimana nilai $\mathrm{Rs}_{\text {hitums }}$ lebih besar dari $\mathrm{Rs}_{\text {tabel }}$ yaitu 0,641>0,409. Sedangkan kemampuan usaha memiliki hubungan sebagai berikut bahwa antara umur dan kemampuan $0,711>0,409$, pendidikan formal terhadap kemampuan 0,696>0,409, pendidikan non formal dan kemampuan $0,775>0,409$, pengalaman usaha dan kemampuan $0,695>0,409$, berarti bahwa memiliki hubungan nyata dimana nilai $\mathrm{Rs}_{\mathrm{hitung}}$ lebih besar $\mathrm{Rs}_{\text {tabel. }}$

\section{Pustaka}

Badan Pusat Statistik Kabupaten Timor Tengah Utara. 2011. Timor Tengah Utara dalam Angka. Badan Pusat Statistik. Kefamenanu.

Badan Pusat Statistik Kabupaten Timor Tengah Utara. 2013. Timor Tengah Utara dalam Angka. Badan Pusat Statistik. Kefamenanu.

Badan Pusat Statistik Provinsi Nusa Tenggara Timur. 2013. Nusa Tenggara Timur dalam Angka. Badan Pusat Statistik. Kupang.

Cartwright, D. dan A. Zander. 1968. Group Dynamics. Pelajar. Yogyakarta.

Charles, J. K. 1991. Kepemimpinan Teori dan Pengembangannya.Terjemahan A.M. Mangunhardjana. Kanisius. Yogyakarta.

Djarwanto Ps. SE. 2001. Mengenal Beberapa Uji Statistik Dalam Penelitian. Liberti Yogyakarta. Yogyakarta.

Mardikanto, T. 1993. Penyuluhan Pembangunan Pertanian. UNS Press, Surakarta.

Santosa, S. 1999. Dinamika Kelompok. Bumi Aksara. Surabaya.

Sears, O.D. , J.L. Freedman dan L. A. Peplas. 1999. Psikologi Sosial. Edisi V. Jilid 2. Erlangga. Jakarta. 